\title{
Design History in the European Province: Suggestions for Research
}

\begin{abstract}
Europe led the way when the first design historiography debates appeared in their day. Those new studies focussed more on researching local histories than on constructing supposedly hegemonic heroic narratives. Yet European micro-history should be related to world macro-history. In an apparently united Europe it is still necessary to cross over a multitude of borders, whether geographical, cultural, political or economic. In exploring intra-European histories we should also add extra-European ones. We are here dealing with the question of recomposing the European design map beyond the known centre, and of studying exchanges in consonance with the methodology proposed by global history. In Europe a diversity of institutions and research groups related to design history have recently appeared. In Spain, and specifically in Barcelona, there are the GRACMON research group of the University of Barcelona, and the History of Design Foundation (Fundación Historia del Diseño).
\end{abstract}

Keywords Microhistory, macrohistory, intra-European, extra-European, GRACMON, Fundación Historia del Diseño, History of Design Foundation.

\section{Introduction}

In recent months we have seen the publication of interesting new studies on the decorative arts and design understood from a global perspective'. We believe that this research responds to an urge to provide a wide overview of material culture from all over the planet, whether traditional or modern, craft-based or industrial. This willingness to contemplate the full spectrum of all countries in the world without discriminating in

'Pat Kirham and Susan Weber (eds.), History of Design: Decorative Arts and Material Culture, 14002000, New York: Bard Graduate Center for Studies in the Decorative Arts, Design \& Culture; New Haven, Conn.: Yale University Press, 2013; Victor Margolin, World History of Design, London: Bloomsbury, 2014. 
any way has also been seen at the ICDHS conferences, where there is a clear intent to go about recomposing the puzzle of design history from a global perspective, thus adjusting it to the reality of highly diverse cultures from places that are geographically far apart.

Europe led research in design history in the early years, in the decades from 1970 to 1990, when the historiographic debate was very intense, above all along the Great BritainUnited States axis. Teleological narratives were questioned as design history evolved towards a more social history focussed on consumption and mass culture, though without ignoring feminist currents, along with a rising interest in the social history of technology. ${ }^{2}$. In recent years the history of European design, following on the models proposed by the French Annales school as well as the definitions of "cultural history" as proposed by Burke, has set out to more deeply explore the crafting of "micro-histories" involving the thorough study of small enterprises, unknown authors or cultural movements that would otherwise have remained outside of the hegemonic tale of industrialization and the triumph of the modern movement. ${ }^{3}$ These micro-histories remind us that there is still a lot to research left to do in the province of Europe. The challenge is to find a way to relate them to macro-history or world history. Our task is to explore them as specific, highly local cases relating to the global world, which would include its flows of commerce and culture.

Europe is comprised of a mosaic of nation states with a highly rich cultural tradition, though for centuries these nations were isolated by geographical, language, political and economic barriers. Since the second half of the twentieth century, due to the implantation of the Common Market first and the treaties of the European Union later, and with the present-day globalization of communication, many of these impediments have disappeared. Even then, there is a persistence of language barriers and others of a bureaucratic nature. On the one hand, any European historian will have a difficult time exploring the culture of a foreign nation without knowledge of its language, disabling him or her from understanding its documentary sources. On the other hand, it cannot be denied that the European Union offers many opportunities in support of projects for scientific collaboration, even though the bureaucracy involved is notorious. Thus European historians are required to make a concerted effort to cross these insidious borders in proposing projects that might more closely examine "intra-European" economic and cultural flow, which though already present in the time of the Roman Empire may now be framed within the context of the modern era.

At the same time, we should also critically examine "extra-European" flows, which have been quite obvious since the time of the colonial empires and were already thoroughly studied by art and decorative arts historians; now, however, with globalization, they have taken on colossal proportions.

\footnotetext{
${ }^{2}$ Kjetil Fallan, Design History. Understanding, Theory and Method, Oxford and New York: Berg Publishers, 2010; Isabel Campi, La historia y las teorías historiográficas del diseño, Mexico City: Editorial Designio, 2013. 
Seen from other continents it could appear that Europe is a homogenous entity, though in reality, apart from the aforementioned language and bureaucratic barriers, it has veritable centres and peripheries. Countries like Spain, Portugal and Greece, which suffered under dictatorships until the 1970s, along with the many countries which for over 40 years years stood on the other side of the Iron Curtain, were for decades relegated to a design periphery in relation to the wealthy, industrialized and democratic centre that made up the nucleus of the European Union. Julier has called these countries "semi-peripheral" or transitional, ${ }^{4}$ to the extent that they all have a developed design culture that has not arisen out of a void, rather being the result of real and effective modernization processes related to political processes that were different from those lived out in the centre. Nowadays we see how the wealth of bibliography on design in the Soviet Union and its satellites demonstrates that under the communist regime a design culture did indeed thrive, though it was quite different from what is understood by the hegemonic design narrative of capitalist nations, especially as told during the Cold War.

Thus, on the one hand, we are obliged to recompose the European design map by including "semi-peripheral" countries that during the long foundational period of the European Union were set off to the side because of dictatorships and block politics. In contrast, new ways of looking at these questions need to be tried. If what we are speaking of is to research intra-European and extra-European flows, then it would seem right for us to take up Adamson, Riello and Teasley's definition of global history as a new methodology:

"Global design history is not a topic but a methodology, one that acknowledges that design as practice and product exists wherever there is human activity, on axes of time as well as space, and recognizes the importance of writing stories that introduce the multi-sited and various nature of design practices. Global design history begins from the conviction that knowledge is always fragmentary, partial and provisional, and only comes into its own through the unexpected challenges, confirmations and elaborations and unsettlings that result from encounter." 5

If we apply the methods of global history to European history, then, as seen with a number of the articles appearing in the volume edited by these authors, we can construct a history of European design that points more decidedly towards the identification of commercial, technological and cultural interchange between nations, putting lesser emphasis on the obsessive identification of authors and institutions.

\footnotetext{
${ }^{4}$ Guy Julier, "Redrawing the Geography of European Design: the Case of Transitional Countries". Paper presented at the European Academy of Design Conference, Stockholm, 1996.

${ }^{5}$ Glenn Adamson, Giorgio Riello and Sarah Teasley, "Introduction: Towards a Global Design History", in Global Design History (eds.), London and New York: Routledge, 2011, pp. 1-10.
} 


\section{The Case of Spain}

While in Spain it might seem that we are somewhat paralyzed by an economic crisis that has obliged us to spend a lot of energy resolving internal problems, we should be pleased that within a short period of time in Barcelona two institutions dedicated to researching and spreading knowledge of design history have emerged: the GRACMON research group (Contemporary Art and Design History Research Group) of the University of Barcelona; and the Fundación Historia del Diseño (Design History Foundation).

Founded in 1986 in the Department of Art History of the Faculty of Fine Arts and the Faculty of Geography and History, GRACMON set out in its early years to research the decorative arts and artistic industries of the periods corresponding to Catalan Modernisme (Art Nouveau) and Noucentisme (a neo-classical movement of the early 2oth century). Later on it opened itself up to the study of design, bringing in design history specialists working on their graduate degrees or recently finished. GRACMON has been recognized by the Catalan government as a consolidated research group and won competitions for research projects in 1999, 2001, 2005 and 2009. Currently it is finishing up the largest research project ever done in Spain on the history of local design. The project appears in two important publications on the Barcelona Design System: From Industry to Art: Shaping a Design Market through Luxury and Fine Crafts (Barcelona 1714-1914); and La formació del Sistema Disseny Barcelona (1914-2014), Un camí de modernitat (The Formation of the Barcelona Design System (1914-2014): a Path of Modernity). ${ }^{6}$

The Fundación Historia del Diseño is considerably younger, having begun its activity in 2008. Its main objectives are to research and promote the history of design throughout the wide community of Spanish-speaking design historians and researchers. Currently there is an initiative to strive as well for the conservation of historical and documentary heritage of Spanish design as an essential body of source material for present and future historians researching local history. The Foundation has collaborated on the publication of books, and has organized courses and activities open to the interested public. In 2011, together with the British Design History Society, it organized the conference Design Activism and Social Change, a project between two European institutions set geographically apart. The conference was an enormous international success. The Foundation has awarded five research grants to international historians and now plans to organize the first meeting of Spanish design historians in conjunction with other organizations. The Foundation has a community of "Friends" in Spain and Latin America who communicate with each other through a forum and collaborate as volunteers on the writing of design history entries for Wikipedia.

\footnotetext{
${ }^{6}$ The first volume was published by Editorial Gustavo Gili, Barcelona, 2013, and is solely in English; the second publication, in a multilingual version for now, was published in 2014 by Publicacions i Edicions de la Universitat de Barcelona.
} 
Within the context of this double "micro" and "macro" dimension of European design history, the Foundation faces two highly stimulating future challenges. On the one hand the goal is to support young historians as well as museums and universities (by means of grants, projects for the conservation of archives and organizational support) in their efforts to rigorously explore local history and thus contribute to the composition of a more balanced and equitable map of European design. On the other hand, the Foundation aspires to continue fulfilling the mandate of the original core objectives. Taking advantage of the possibilities arising from information and communication technologies, the idea is to provide incentives (through real or virtual encounters, the use of Wikipedia, or in forums, to give a few possibilities) for communication between historians working in areas of local history, thus ensuring that their research might be appropriately inserted into the context of European and global history. In this sense the fact of working intensely in three languages (Catalan, Spanish and English) makes it considerably easier to open up these projects, which in this way might move comfortably between the "micro-history" and "macro-history" we have referred to here.

\section{Conclusion and Suggestions:}

There is no doubt that European national institutions are being called upon to collaborate with each other. There are hundreds of projects to be undertaken and one does not need to have a very rich imagination to come up with them. The Common Market came into being shortly after the Second World War and the movement of goods was put into place well before the free movement of citizens was ever considered. Previous to the elimination of borders inside the Union (The Schengen Agreement, implemented in 1995) and the single currency being put into place (the Euro, in 2002), there was movement across borders of cinema, television, music, magazines and an endless stream of cultural and consumer products, good design included, making it possible to take on new consumer habits and acquire new fashions and trends, all of which should be understood as processes of modernization. It is even surprising to find out to what point European citizens who were denied access to the democratic and consumer oasis of the Common Market were in fact up to date on what was emerging in London, Paris, Milan and Berlin.

An interesting example of "intra-European" history that could be explored would be in the study of the relations between Mediterranean countries. For example, it would be possible to study to what degree Italy, in the decades following the Second World War, was able to provide models for architecture and design that would later be interpreted in original ways in France, Spain, Turkey and Greece.

Other cases suggested have to do with the inclusion on the part of Mediterranean countries of Anglo-Saxon pop and underground culture from the 1960 s and 1970s, or, in contrast, the question of how in the 1980 Anglo-Saxon and Central European countries were able to assimilate the postmodern currents emerging out of the Mediterranean. 
